\title{
Assessment of the Impact of Road Transport Change on the Security of the Urban Social Environment
}

\author{
Rolandas Vitkūnas ${ }^{1}$, Renata Činčikaitè ${ }^{2}$ and Ieva Meidute-Kavaliauskiene ${ }^{1, *(D)}$ \\ 1 Research Group on Logistics and Defense Technology Management, General Jonas Žemaitis Military \\ Academy of Lithuania, Silo St. 5A, LT-10322 Vilnius, Lithuania; rolandas.vitkunas@lka.lt \\ 2 Business Management Faculty, Vilnius Gediminas Technical University, Saulètekio al. 11, \\ LT-10223 Vilnius, Lithuania; renata.cincikaite@vilniustech.lt \\ * Correspondence: ieva.meidute@lka.lt
}

Citation: Vitkūnas, R.; Činčikaitė, R.;

Meidute-Kavaliauskiene, I.

Assessment of the Impact of Road Transport Change on the Security of the Urban Social Environment. Sustainability 2021, 13, 12630. https:// doi.org/10.3390/su132212630

Academic Editor: Luigi Dell'Olio

Received: 15 October 2021

Accepted: 11 November 2021

Published: 16 November 2021

Publisher's Note: MDPI stays neutral with regard to jurisdictional claims in published maps and institutional affiliations.

Copyright: (c) 2021 by the authors. Licensee MDPI, Basel, Switzerland. This article is an open access article distributed under the terms and conditions of the Creative Commons Attribution (CC BY) license (https:// creativecommons.org/licenses/by/ $4.0 /)$.

\begin{abstract}
In the context of accelerating urbanisation, cities must ensure a viable economy, social wellbeing, and a healthy environment. Transport is one of the key conditions for economic development and meeting the needs of countries, regions, and cities. However, transport must meet not only the physiological but also the social needs of society, one of which is environmental security. Urban transport accounts for around $40 \%$ of $\mathrm{CO}_{2}$ emissions and $70 \%$ of other pollutants from road transport. Thus, one of the most difficult issues for any city to address when building bypasses is the growing number of cars in the city, traffic congestion, and the reduction of all greenhouse gas emissions. The documents adopted in July 2020 aim to revitalise the EU's economy by moving towards a green economy and sustainability. In addition to the systematic and comparative analysis of concepts published in the scientific literature, the article also presents an analysis of the concepts of the sustainable city and sustainable transport, as well as a study of the social impact of bypasses and the assessment of the security of the social environment in the Baltic capitals. The aim of the article is to assess the impact of the growing number of vehicles on the security of the city's social environment. Research results show that the number of pollutants and a direct dependence between the number of pollutants and the driving speed were established. Therefore, it needs to make investments in the transport sector: improving roads, the construction of bypasses, and the technical parameters of purchased cars.
\end{abstract}

Keywords: sustainable city; sustainable transport; security of social environment

\section{Introduction}

The scientific literature [1-6] points out that infrastructure is a key condition for economic development and meeting the needs of countries, regions, and cities and emphasises its importance for the economic development of lagging cities. Infrastructure is important for both urban residents: businesses and tourists. Most of the time, it is designed to meet the needs of citizens and city guests and makes the city more accessible. Researchers, emphasising the impact of infrastructure on the accessibility of a city or region, also emphasise the effect of reducing the accessibility costs of the territory and increasing the opportunities to access resources. Roads, pipelines, airports, railways, power lines, gas pipelines, sewerage/drainage systems, information technology, and telecommunications infrastructure are generally considered to be physical infrastructure. Studies and calculations by various researchers have shown that physical infrastructure correlates with GDP, labour productivity, and investment. For example, the European Commission estimates that, through the implementation of the project TransEuropeanNetwork (TEN), the European Union's GDP will increase by $0.25 \%$ and employment by $0.11 \%$ between 2005 and 2025, and 800,000 jobs will be created [7]. However, the development of physical infrastructure also has another side to it. A study by the European Environment Agency (EEA) [8] indicates that as much as $88 \%$ of the population in European cities is affected by pollution. Urban 
transport accounts for around $40 \%$ of $\mathrm{CO}_{2}$ emissions and $70 \%$ of other pollutants from road transport. As early as 1987, in order to address the problems caused by urbanisation processes, the UN's World Commission on Environment and Development (WCED) issued a report entitled "Our Common Future", which had the greatest impact on the emergence of the concept of sustainable development. The report emphasised the need for sustainable socio-economic development that would also take into account ecological factors. The authors [9-13] also emphasised the need to implement the principles of sustainable urban development for urban development. The authors of the article agreed with the need to pursue sustainable socio-economic development that would take into account ecological factors and conducted an analysis of the scientific literature on the concepts of the sustainable city and sustainable transport.

\section{Sustainable City}

In the scientific literature, a sustainable city is defined as the improvement of the quality of life in a city, including ecological, cultural, political, institutional, social, and economic components, without leaving a burden on future generations. Urban sustainability aims to reduce the consumption of natural resources and the generation of waste in the city, thus improving the habitability and quality of coexistence of local, regional, and global ecosystems [14]. Zhao (2014) described a sustainable city as a city that ensures adequate well-being for its people by maintaining and improving the urban ecosystem and services provided [15]. Urban sustainability is an "adaptive" process that facilitates and sustains a coordinated virtual cycle of ecosystem services and human well-being [16,17]. According to researchers [3,10], a sustainable city is liveable, efficient, and environmentally friendly. The following dimensions must be ensured in such a city: social, economic, and ecological. Sustainable urban development is the improvement of the quality of life in a city, including ecological, cultural, political, institutional, social, and economic components, without leaving a burden on future generations. In the scientific literature [18-24] and in various strategic documents (e.g., European Innovation Partnership on Smart Cities and Communities: Strategic Implementation Plan (2013) [25], Lithuanian Progress Strategy "LITHUANIA 2030" [26], and National Progress Programme for the period 2014-2020 [27]), "smart" city is a particularly popular term. It is most often defined as a city of high quality of life and competitiveness. Researchers [18-24] emphasise that digital infrastructure and data, information technology, and telecommunications, which drive economic progress but have a weak impact on the environment and ecosystems, are of particular importance for sustainable urban development. According to [28], sustainable development is understood in the scientific literature as a complex concept and a complicated process [29] aimed at ensuring prosperity not only for the present but also for future generations. Marin et al. [30] emphasise the depletion of key resources, while Cioca et al. [31] describe sustainable development as development that maintains the stability of the system and develops a balance between economic, social, and environmental development without endangering future generations. However, according to the European Environment Agency (EEA) for the year 2015 [32], one in four urban dwellers in Europe lived in cities where air quality standards were exceeded, of which more than $95 \%$ lived in an environment where air pollutants could harm the social environment and its security.

\section{Sustainable Social Environment and Its Security}

In the scientific literature, the concept of a sustainable social environment is defined differently. Bruneckienè et al. [1,33] distinguish four sectors: public transport, health and social security, education and science, and public security infrastructure. Panda [34] highlights the following factors: the ability to meet basic needs, house, health protection, security, education, personal capital, demography, poverty rate, culture, recreational areas, and access to credit, which all add up and complement each other. Činčikaite and Paliulis [35] described the social environment through the following factors: human capital; migration; social burden on the city; urban security; community learning, partnership. 
and activism; social, cultural, and sports infrastructure; the education and training system; the psychological climate of the city; the demographic situation of the city; and medical protection infrastructure. These authors supplement the classifications already discussed with the following factors: migration, social burden on the city, community learning, psychological climate, and partnership and activism. Whilst examining the concept of security in the social environment, it has been observed that the security factor is usually understood as physical security (protection from any situation that endangers a person's physical security - it can be crime and violence). However, a secure environment is the only appropriate environment in which human rights and freedoms can be exercised and developed. The sense of security determines both the behaviour and quality of life of individuals, as well as the social and political stability of the state and the confidence of the population in the legal and institutional mechanisms functioning in it $[36,37]$. The authors of the article define the concept of urban social environment security as physical security, health security, urban social security, educational security, security of house purchase, income security, and psychological security [38].

\section{The Impact of Road Transport on Sustainable Urban Development}

Researchers define the concept of sustainable transport differently [39-47]; for instance, sustainable transport is transport services that justify spending on social needs and environmental protection, and are optimally adapted to the needs of the city. Transport needs - mobility and security - must be reconciled with the goals of the quality of the urban environment and the comfort of living in areas [39]. A sustainable transport system is one in which fuel consumption, vehicle emissions, security, traffic congestion, and socio-economic factors do not have irreversible consequences for future generations [40]. Sustainable transport does not pose a threat to public health or the ecosystem and ensures that long-term goals for the use of renewable sources are met [41]. The goal of sustainable transport is to ensure that environmental, social, and economic factors influence all decisions concerning the transport system [42]. According to the European Environment Agency (EEA), a sustainable transport system is one that reduces the need for non-renewable sources, as well as the adverse effects on the environment and human health. It also seeks to make mobility accessible so that services, jobs, and education are easily accessible as we travel more and more [43]. A sustainable transport system includes transport that is not based on the use of fossil fuels [44] and transport that is accessible, efficient, financially sustainable, environmentally friendly, and safe. [45] It is the development of society, enabling the common good to be attained for the present and future generations while reconciling the environmental, economic, and social objectives of society and staying within the limits of their environmental impact [46]. It represents inclusion and the consideration of ecological, social, and economic factors in transport activities [47].

Researchers [48] highlighted the main reasons influencing the development of sustainable transport: incompatibility of infrastructure, dependence on fossil fuels, a low level of security, tax and price distortions, increasing $\mathrm{CO}_{2}$ emissions from transport, changing mobility needs, and increasing traffic congestion. The traffic congestion has a negative impact on the economy, the social sphere, health, and the environment. The air is mostly polluted during start-up, braking, and slow driving. It was found that air pollution is 50 times higher than the general average at the point when the car starts to move. Increasing the speed to $90 \mathrm{~km} / \mathrm{h}$ reduces fuel consumption and emits less than half the number of pollutants. Cars have another negative effect: when moving, vehicles cause vortices and raise dust together with health-hazardous micro-organisms [49].

Transport is one of the most important factors in ensuring economic development and people's quality of life. Investment in transport infrastructure has a significant impact on economic growth $[50,51]$. The importance of the sector is also reflected in Lithuania's macroeconomic indicators, as the share of gross domestic product (GDP) generated by the transport sector in 2019 was 13\%, making it one of the most important sectors in the 
country. In 2019 , about $8 \%$ of all employed people in the country worked in the transport and storage sector [52].

Scientific literature indicates that the main urban transport problems are the following: increasing traffic congestion [53], which influences the increase in the number of traffic accidents, travel time [54], and transit of urban transport through urban areas [55]. EU reports highlight the following problems in the transport system [56]: traffic congestion, sustainability, air quality, quality of transport infrastructure, and competition.

Much time is lost in traffic congestion, as indicated in the report "Development of Methodology and Model Intended for Assessment of Socio-Economic Impact of Investments Financed from the European Union Structural Funds and the National Budget Funds of Lithuania". The final report can be assessed from a financial point of view. This report contains time rates estimating the cost of one hour for a person travelling for work (EUR 11.99) and non-work purposes (EUR 4.80).

One of the largest problems in big cities is traffic congestion, and cities are starting to build bypasses to eliminate it. According to the insights of Juškevičius [13], the greatest benefit is achieved by forming a ring of bypasses around the entire city. Such a bypass system diverts transit traffic away from the city and decentralises motor traffic.

The impact of bypasses was examined, taking Vilnius as an example [57], and it was found that the travel distance decreases from 4.7 to $3.5 \mathrm{~km}$, the number of traffic lights decreases from 10 to 0 , travel time during off-peak hours is reduced from $11 \mathrm{~min}$ to $3 \mathrm{~min}$ $58 \mathrm{~s}$, travel time during the morning peak (from 7:00 to 8:30) is reduced from $32 \mathrm{~min}$ to $3 \mathrm{~min} 58 \mathrm{~s}$, and the average speed increases from 8.8 to $52.9 \mathrm{~km} / \mathrm{h}$.

\section{Air Pollution}

With increasing atmospheric pollution worldwide, special attention is being paid to atmospheric pollution by particulate matter. According to global health data, one in eight deaths are caused by atmospheric pollution [58].

Atmospheric pollution by particulate matter is one of the main problems of ambient air quality in cities [59]. According to statistics from the World Health Organisation (WHO), atmospheric pollution causes 3.7 million premature deaths each year [60]. A total of 2.4 million deaths occur each year from diseases caused by particulate matter [61]. Particulate matter that enters the human body causes diseases such as asthma, bronchitis, cardiovascular disease and lung cancer [62], eye diseases, cancer, birth defects, and increased susceptibility to viral ailments [63] and can also worsen the psychological condition of humans [64]. A correlation has been found to exist between air pollution and the number of respiratory and cardiovascular diseases [65]. As air pollution increases, so does the number of instances of such diseases. Signoretta et al. [65] found a link between the psychological state of a human being and ambient air pollution. As air pollution increases, people experience more psychological problems, are more responsive to stress, feel increasingly worse, suffer from fatigue, and are in a bad mood. The World Health Organisation (WHO) [60] estimates that environmental stressors in Europe, one of which is air pollution, account for around 15-20\% of deaths. In 2017, an assessment of the effects of air pollution on the central nervous system of children and adults was performed. This study revealed that elevated PM2.5 concentrations have an effect on adult episodic memory and may be one of the factors causing increasing depressive disorders. The increase in NO2 concentrations is associated with dementia and NOx with Parkinson's disease. Researchers have categorically stated that air pollution has a significant adverse effect on the central nervous system of both children and adults and is a significant risk factor for public health [66]. The main air polluters are thermal power stations and boiler houses, industrial firms, and transport. In Lithuania's largest cities, mobile air pollution sources account for around $75-80 \%$ of total air emissions. As there is an intensive concentration of industry and cars in cities, it is assumed that air pollution is highest in metropolitan areas, and it is there that air pollution causes the most deaths and illnesses. 


\section{Methodology}

The study consists of two parts. The first part presents the security assessment of the social environment in the context of increasing road transport. The assessment is performed based on the MDK model [6,35]. With their empirical research, the authors of the article seek to determine the assessment and dynamics of the security of the sustainable social environment in the Baltic capitals over the period of 2015-2020 in terms of increasing road transport. Analysis of the scientific literature [21,67-69] has shown that multi-criteria assessment methods can be successfully applied in the assessment of various multidimensional sustainable development processes or socio-economic phenomena, as they can help to perform such tasks as selection, sorting, ranking, and characterisation. Thus, in order to evaluate the assessment of urban social environment security in the context of increasing road transport as objectively and accurately as possible, the authors choose the multi-criteria assessment method COPRAS (complex proportional assessment method) [67-69], and the data are normalised by transforming them into a dimensionless form according to the following Formula (1):

$$
\widetilde{r}_{i j}=\frac{r_{i j} w_{i}}{\sum_{j=1}^{n} r_{i j}}
$$

where $w_{i}$ is the weight of the $i$-th indicator; $r_{i j}$ is the value of the $i$-th indicator for the $j$-th object.

The priority of objects is determined. The higher the $Q_{j}$, the higher the efficiency (priority) of the variant (2).

$$
Q_{j}=S_{+j}+\frac{S_{-\min } \times \sum_{j=1}^{n} S_{-j}}{S_{-j} \times \sum_{j=1}^{n} \frac{S_{-\min }}{S_{-j}}}
$$

where

$S_{-j}$-the sum of minimising normalised indicators

$S_{+j}$ - the sum of the maximising normalised indicators

$S_{- \text {min }}$-minimum value of minimising normalised indicators

In the second part, the aim of the assessment is to determine the impact of high-speed streets and bypasses on urban pollution, following the example of the Vilnius Western Bypass. According to the hypothesis formed when performing an analysis of scientific evidence stating that road transport pollution and emissions decrease with increasing speed up to a certain limit and then increase again [70-74], the speed on bypasses and high-speed streets is considered to be higher than on urban streets within the territorial limits where emissions in $\mathrm{g} / \mathrm{km}$ are lower. We want to note this example: as the speed of car traffic increases to the limit of 70-90 km/h, the pollution decreases and then starts to increase again. Therefore, on bypasses and expressways where speed limits are limited to $70-90 \mathrm{~km} / \mathrm{h}$, pollution is lower than on city streets, where speeds are limited to $50 \mathrm{~km} / \mathrm{h}$ and real speeds are around $30 \mathrm{~km} / \mathrm{h}$. Calculations of emissions from cars on city streets consist of two parts [75]. The first part of the calculation covers the pollution of car traffic on the streets between regulated junctions, and the second covers pollution at regulated junctions. Car traffic intensities on the streets are divided into zones, which are then considered separately. Pollution is calculated separately for each zone or junction. In this 
way, in order to calculate the total car pollution in a certain part of the road, we calculate the pollution in the sections and junctions that make up the analysed road.

$$
M_{T}=\sum_{i}^{n} M_{S}^{i}+\sum_{j}^{m} M_{J}^{j}
$$

where $M_{T}$ is total car pollution on the road stretch to be analysed, g over the period of a certain unit of time (we can choose it ourselves); $M_{S}^{i}$ is car pollution on the road section to be analysed $i$, g over the period of a certain unit of time; $M_{J}^{j}$ is car pollution on the road junction $j$, g over the period of a certain unit of time.

The determination of pollutants caused by car traffic on the streets between road junctions is calculated [75] as the number of $i$-th pollution particles emitted by car traffic $(\mathrm{g} / \mathrm{s}), L$-in the kilometre section according to Formula (4):

$$
M_{S}^{i}=\frac{L}{3600} \sum_{1}^{k} m_{i k}^{n p} V_{k}^{h} r_{i v}
$$

where $L$ is length of the street in the stretch of the analysed section, $\mathrm{km} ; m_{i k}^{n p}$ is the $i$-th emissions of the $k$-th car group when operating the car in the city (Table 1$) ; k$ is number of car groups; $V_{k}^{h}$ is the intensity of movement of the $k$-th group, number of cars (pcs) within an hour (h); $r_{i v}$ is the adjustment factor estimating the average speed of car traffic in the stretch of the analysed section (Table 1).

Table 1. Emission values $(\mathrm{g} / \mathrm{km})$ for different classes of cars $m_{i k}^{n p}$ [75].

\begin{tabular}{cccccccc}
\hline \multirow{2}{*}{ No. } & \multirow{2}{*}{ Car Class } & \multicolumn{5}{c}{ Emissions, $\mathbf{g} / \mathbf{k m}$} \\
\cline { 3 - 8 } & & $\mathbf{C O}$ & $\mathbf{N O}_{2}$ & $\mathbf{C H}$ & $\mathbf{P M}$ & $\mathbf{S O}_{2}$ \\
\hline 1 & Passenger car & 2 & 0.7 & 0.4 & 0.02 & 0.03 \\
\hline 2 & Minibus & 4.5 & 2 & 2.5 & 0.08 & 0.06 \\
\hline 3 & Bus & 7 & 6 & 5 & 0.3 & 0.07 \\
\hline 4 & Heavy goods vehicle & 9 & 7 & 5.5 & 0.4 & 0.1 \\
\hline 5 & Heavy goods vehicle with a trailer or semi-trailer & 12 & 8 & 6.5 & 0.5 & 0.12 \\
\hline 6 & Hybrid cars & 1.04 & 0.36 & 0.21 & 0.01 & 0.02 \\
\hline
\end{tabular}

As the traffic of cars fluctuates significantly during the day, it is possible to calculate the pollution in the stretch of the analysed section:

$$
M_{S}^{i}=L \sum_{1}^{k} m_{i k}^{n p} V_{k} r_{i v}
$$

When determining the emissions of harmful substances in the traffic flow at the regulated junction $j$, the duration of operation of the prohibitory signal, periodicity, and emissions according to individual types of harmful substances during parking time are evaluated [75] (Formula (6)):

$$
M_{J}^{j}=\frac{R}{40} \sum_{n=1}^{N_{c}} \sum_{k=1}^{N_{g r}}\left(m_{i k}^{e l} Q_{\max }^{k}\right)
$$

Here, $R$ is the average duration of the prohibitory traffic signal, in minutes; $N_{c}$ is the number of prohibitory traffic signals in a period of $20 \mathrm{~min} ; N_{g r}$ is the number of car groups; $m_{i k}^{e l}$ is emissions of the $i$-th substance $(\mathrm{g} / \mathrm{min})$ of cars in the comparison $k$-th group standing in front of prohibitory traffic signals; $Q_{\max }^{k}$ is the row length of the $k$-th group 
of cars parked in the junction zone at the end of the $n$-th prohibitory traffic signal; $N_{g r}$ is $\mathrm{g} / \mathrm{min}$, calculated by summing the lengths of the vehicles approaching the junction. This is done in two stages: the length of all vehicles is determined, and the lengths of each vehicle are determined. At the end of the prohibitory traffic signal, the length of the row approaching the junction is determined for each direction according to Formula (7):

$$
Q_{\max }=\frac{V R}{3600\left(1-\frac{V}{S}\right)}
$$

Here, $R$ is the average duration of the prohibitory traffic signal burning, in seconds; $S$ is the traffic flow rate in the lane, the intensity of queuing of vehicles, cars $/ \mathrm{h} ; N_{c}$ is the number of prohibitory traffic signals over the period of $20 \mathrm{~min}$, calculated according to Formula (8):

$$
N_{c}=\frac{1200}{c}
$$

When calculating the numbers of harmful substances in the junction zone, it is assumed that at the end of each prohibitory traffic signal during the selected interval of $20 \mathrm{~min}$, the composition and length of the traffic flow will be the same.

\section{Calculating Pollution on the Bypass and in the City}

When performing pollution calculations for car traffic on the Western Bypass (see Table 1), car traffic volumes were grouped by type and time. The lengths of the segments between the traffic flow variation points are given.

$$
M_{S}^{A}=M_{S}^{A 1}+M_{S}^{A 2}+M_{S}^{A 3}
$$

Here, $M_{S}^{A}$ is the total number of pollutants in the traffic of cars going around the bypass, $g ; M_{S}^{A 1}, M_{S}^{A 2}, M_{S}^{A 3}$ is the number of pollutants in the traffic of cars moving in separate sections (stretches) of the bypass, $\mathrm{g}$.

The number of pollutants $M_{S}^{A}$ on a separate bypass section is calculated:

$$
M_{S}^{A i}=L_{i}^{A} \sum_{t=1}^{3} r_{t v}^{A}\left(\sum_{j=1}^{5} m_{z j}^{n p} V_{i t j}\right)
$$

Here, $L_{i}^{A}$ is the length of the $i$-th bypass section, $\mathrm{km} ; r_{t v}^{A}$ is the coefficient estimating the variation of emissions depending on the speed of movement (Table 1), where index $A$ means measurements in the speed bypass, $t$ is the index for one of the three measurement periods; $m_{z j}^{n p}$ is the $z$-th emission of the $j$-th car group (there are five groups excluded) during the operation of the car in the city, $\mathrm{g} / \mathrm{km} ; V_{i t j}$ is the number of group $\mathrm{j}$ cars in the $i$-th section over the time period $(\mathrm{t})$ of measurements.

The total emissions on a bypass are calculated:

$$
M_{S}^{A}=\sum_{i=1}^{3} L_{i}^{A}\left(\sum_{t=1}^{3} r_{t v}^{A}\left(\sum_{j=1}^{5} m_{z j}^{n p} V_{i t j}\right)\right)
$$

The number of pollutants in the city can be calculated:

$$
M_{S}^{C}=L^{C}\left(\sum_{t=1}^{3} r_{t v}^{C}\left(\sum_{j=1}^{5} m_{z j}^{n p} V_{i t j}\right)\right)
$$

By comparing Formulas (11) and (12) in relative terms, it is possible to determine the indicators on which pollution depends on the analogous composition of traffic flows:

$$
K_{i}=\frac{L_{i}^{A} r_{t v}^{A}}{L_{i}^{C} r_{t v}^{C}}
$$


Here, $K_{i}$ is a coefficient showing the ratio of bypass pollution to the city streets used to achieve the same transportation goal; $L_{i}^{A}$ and $L_{i}^{C}$, respectively, are the distances travelled on the bypass and city streets to reach the same transport destination, $\mathrm{km} ; r_{t v}^{A}$ and $r_{t v}^{C}$ are coefficients estimating the variation of emissions depending on the speed of movement on the bypass $(A)$ and city streets $(C)$, respectively. If the obtained coefficient $K$ is more than one, more emissions are emitted when transporting goods by bypass, and if it is less than one, it is more efficient to carry out transportation by bypass, and fewer emissions are emitted by the traffic flow.

\section{Research}

A study of the scientific literature lacks a comprehensive assessment of the security of the urban social environment in the context of increasing road transport. The aim of this article is to determine which city occupies the best social security situation among the capitals of the Baltic States in terms of increasing road transport. The capitals of the Baltic States have been selected for the study due to their geographical location and historical, political, and economic past.

Security is not just physical security, which is what many scientists analysing the topic of urban competitiveness talk about. Security is defined by the authors of the article as physical security, health security, urban social security, educational security, housing security, income security, and psychological security. The research uses the MDK model, which is based on the principle of program-targeted management, which provides an opportunity to predict the influence of factors, as well as their importance in achieving the set goal.

The number of registered cars is growing every year (see Figure 1). Having compared 2020 to 2019, an increase of 2.5\% has been noticed in Tallinn, 2.23\% in Riga, and 2.36\% in Vilnius.

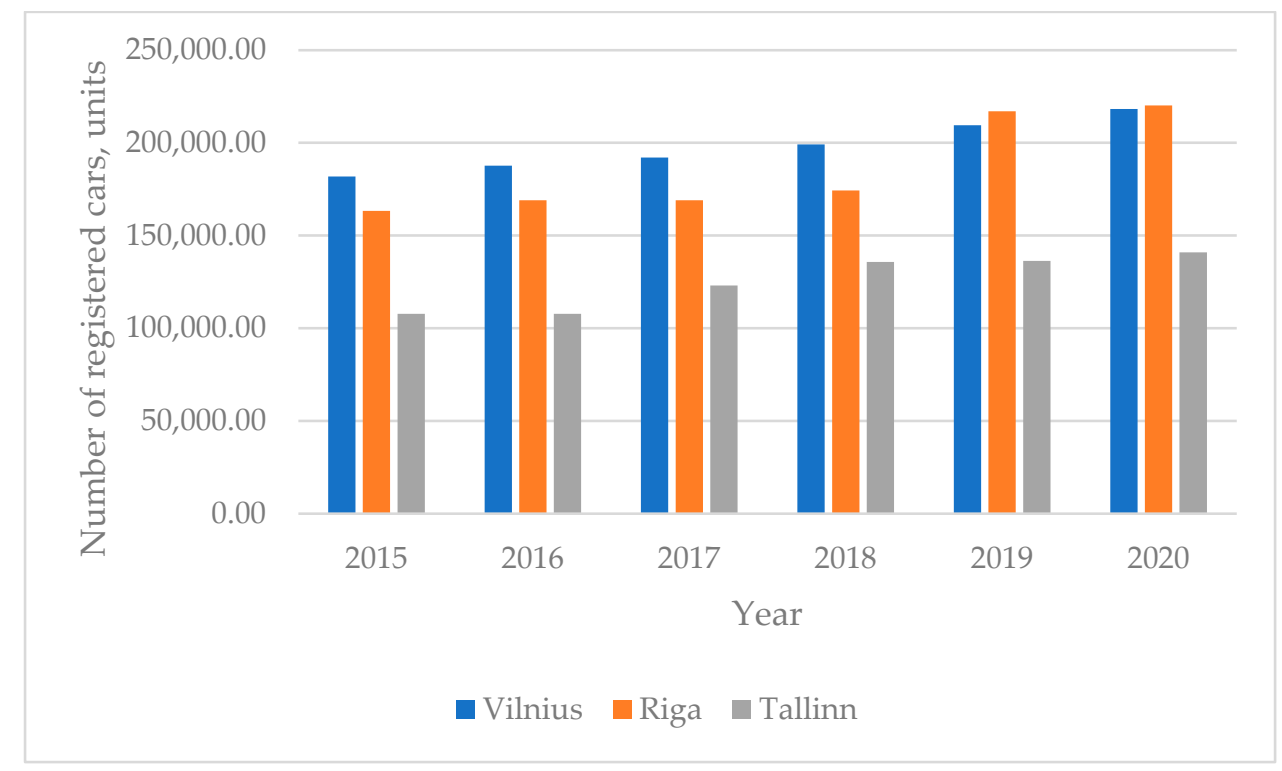

Figure 1. Number of registered cars (in the period 2015-2020) (according to Eurostat).

Meanwhile, comparing 2020 to 2015, an increase of 19.01\% is observed, $28.14 \%$ in Riga and $13.76 \%$ in Vilnius. Based on the country rankings according to the logistics activity index, published by the World Bank, in 2018, Estonia ranked 36th, Lithuania 54th, and Latvia 70 th.

In order to assess the assessment of the security of the social environment of the Baltic capitals in terms of increasing road transport, data covering the period of 2014-2020 (Eurostat, Lithuanian, Latvian and Estonian Department of Statistics) were used. Statistical assessment methods are used to assess the security of the social environment of the Baltic 
capitals in terms of increasing road transport. Their result is determined by the possibilities of obtaining information.

The assessment score is calculated according to Formula (14):

$$
\begin{aligned}
& I_{M_{10}}=0.1 M_{110}+0.1 M_{17}+0.1 M_{19}+0.1 M_{111}+0.1 M_{212}+0.1 M_{213}+ \\
& +0.1 M_{215}+0.1 M_{216}+0.1 M_{214}+0.1 M_{217}
\end{aligned}
$$

where

$M_{110}$-Value of the urban demographic situation factor;

$M_{17}$-Value of the social, cultural, and sports infrastructure factor;

$M_{19}$-Value of the medical protection infrastructure factor;

$M_{111}$-Value of the education system factor;

$M_{212}$ - Value of the human capital factor;

$M_{213}$-Value of the migration factor;

$M_{215}$-Value of the urban security factor;

$M_{216}$-Value of the community learning, partnership, and activism factor;

$M_{214}$-Value of the social burden factor for the city;

$M_{217}$-Value of the sustainable urban transport factor.

According to the data shown in Figure 2, Vilnius leads in the whole period under review (2014-2020). A very significant gap between Tallinn and Riga was observed in 2020, the reasons for which may be investments in the transport sector, improvement of roads, construction of bypasses, and technical parameters of purchased cars.

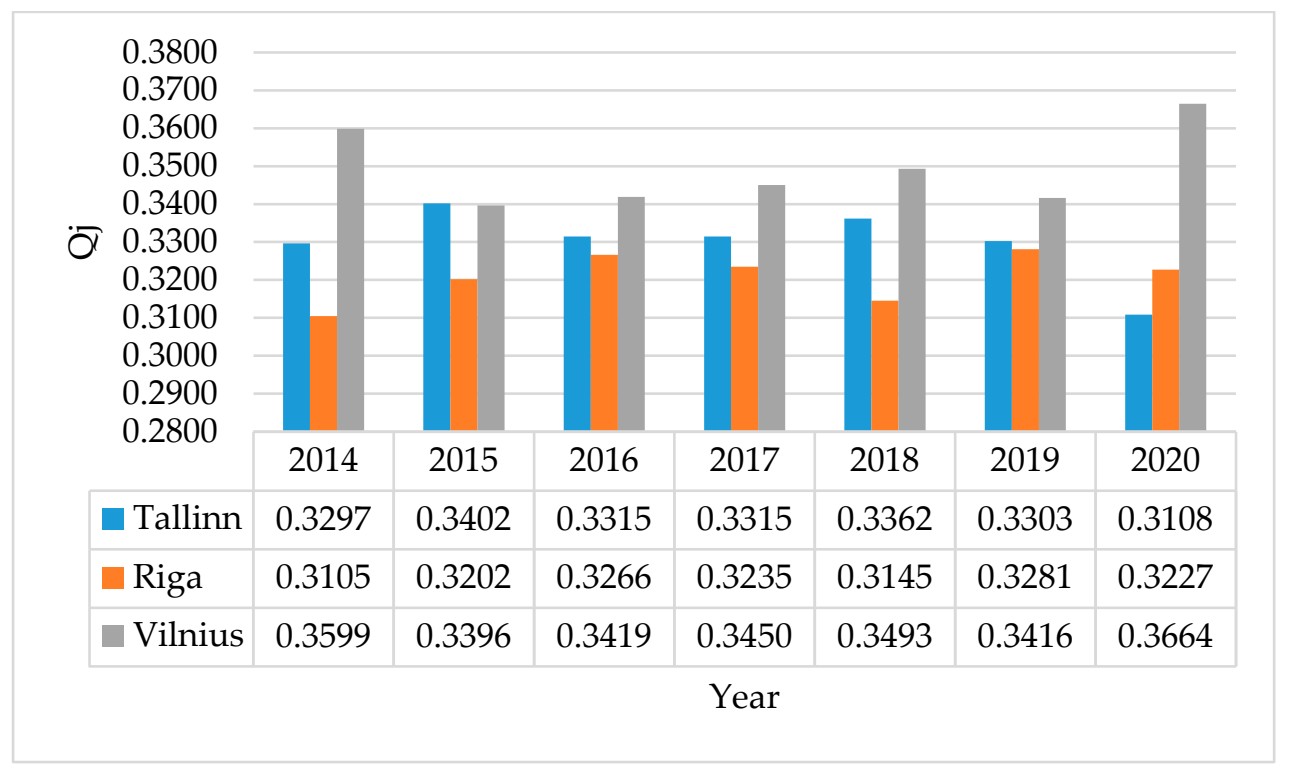

Figure 2. Results of the assessment of the security of the social environment $Q_{j}$ of the Baltic capitals in the aspect of increasing road transport (in the period 2014-2020).

The second study aims to determine the extent to which the construction of bypasses contributes to the reduction of air pollution, following the example of Vilnius. The Vilnius City Western Bypass was built with the aim of relieving traffic in the city centre. The bypass also helped to avoid junctions controlled by traffic lights and increased the maximum speed limit to $90 \mathrm{~km} / \mathrm{h}$ (leaving restrictions up to $70 \mathrm{~km} / \mathrm{h}$ only for traffic jams or exit sections). In this way, the driving speed between the main directions of traffic flows passing through Vilnius has been increased.

A passenger car, a minibus, a bus, a heavy goods vehicle, and a heavy goods vehicle with a trailer or semi-trailer were distinguished.

Measurements are made in the sections defined in the figure. The points in Figure 3 are marked with the appropriate code and name. 


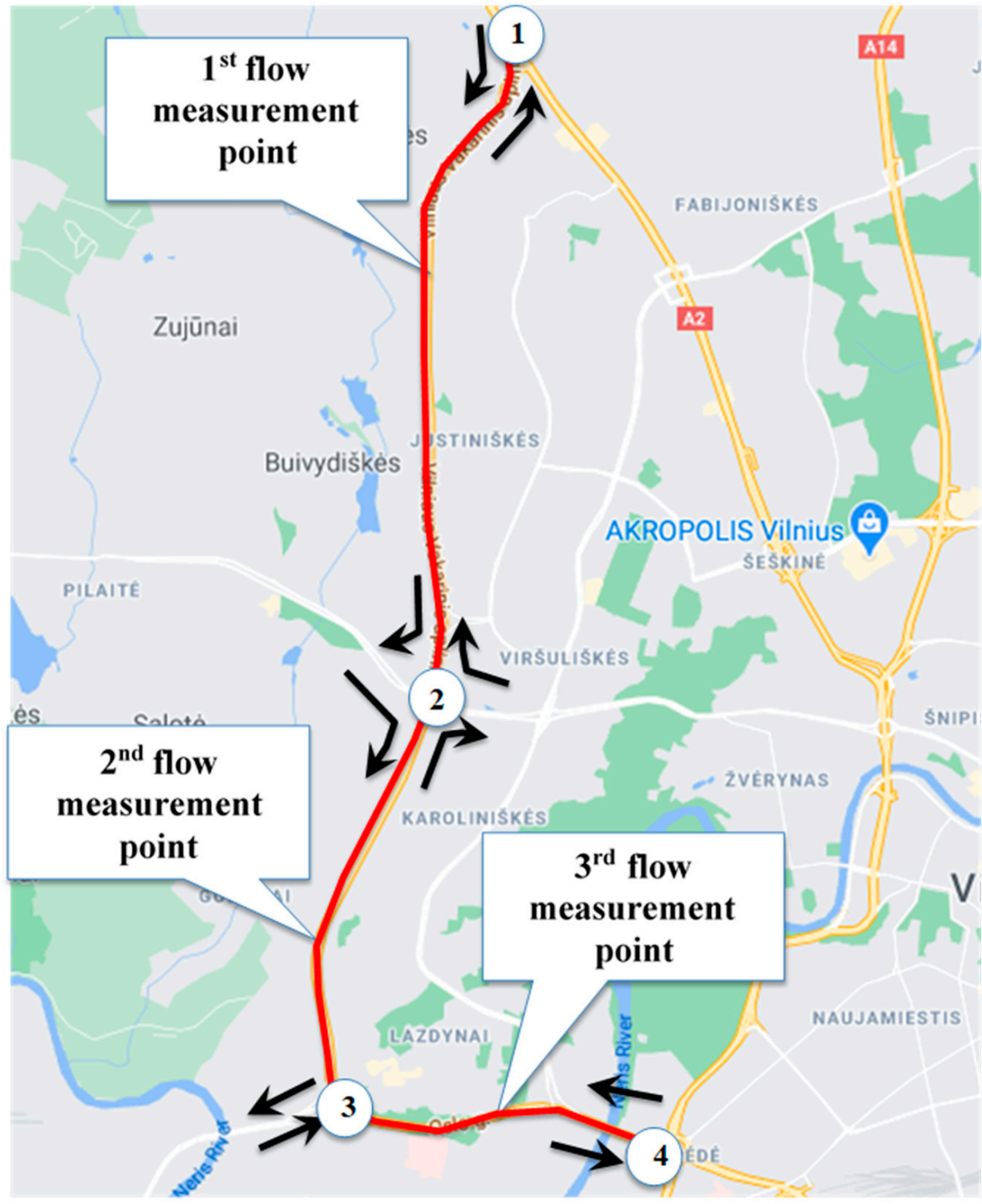

Figure 3. Vilnius City Western Bypass, main traffic flow directions, and bypass traffic flow measurement points.

Having performed the measurements, the data were converted into the amount of car traffic per hour. Traffic flows in both directions of the bypass were determined. The data obtained are presented in Tables 2 and 3 . The distance between points was found to be $1-2$ is $6.6 \mathrm{~km}$, between $2-3-3.9 \mathrm{~km}$, between $3-4-2.1 \mathrm{~km}$, and a total of $12.6 \mathrm{~km}$. When driving through the city streets (Geležinio Vilko St. or Ukmergè St.), we will obtain the distance of $13.3 \mathrm{~km}$ between the end points.

Table 2. Summarised driving speeds of Vilnius city car flows and values of pollution adjustment factor $r_{i v}$.

\begin{tabular}{ccccccc}
\hline & $\begin{array}{c}\text { Average Traffic } \\
\text { Speed during } \\
\text { Peak km/h }\end{array}$ & $\begin{array}{c}\text { Adjustment } \\
\text { Factor } \boldsymbol{r}_{i v}\end{array}$ & $\begin{array}{c}\text { Average Traffic } \\
\text { Speed during } \\
\text { Off-Peak km/h }\end{array}$ & $\begin{array}{c}\text { Adjustment } \\
\text { Factor } \boldsymbol{r}_{\boldsymbol{i v}}\end{array}$ & $\begin{array}{c}\text { Average Speed } \\
\text { at Night km/h }\end{array}$ & $\begin{array}{c}\text { Adjustment } \\
\text { Factor } \boldsymbol{r}_{\boldsymbol{i v}}\end{array}$ \\
\hline On bypass & 41.0 & 0.73 & 79.3 & 0.49 & 82.8 & 0.52 \\
\hline On city streets & 14.4 & 1.29 & 26.2 & 1.08 & 45.7 & 0.62 \\
\hline
\end{tabular}


Table 3. Percentage of pollution reduction in Vilnius city achieved by driving through bypass.

\begin{tabular}{|c|c|c|c|c|c|c|}
\hline Stretch & Type of Transport & $\mathrm{CO}$ & $\mathrm{NO}_{2}$ & $\mathbf{C H}$ & $\mathbf{P M}$ & $\mathrm{SO}_{2}$ \\
\hline \multirow[t]{5}{*}{ Ukmergè } & Passenger cars & $46.24 \%$ & $46.24 \%$ & $46.24 \%$ & $46.24 \%$ & $46.24 \%$ \\
\hline & Minibuses & $47.90 \%$ & $47.90 \%$ & $47.90 \%$ & $47.90 \%$ & $47.90 \%$ \\
\hline & Buses & $48.93 \%$ & $48.93 \%$ & $48.93 \%$ & $48.93 \%$ & $48.93 \%$ \\
\hline & Heavy goods vehicles & $48.23 \%$ & $48.23 \%$ & $48.23 \%$ & $48.23 \%$ & $48.23 \%$ \\
\hline & Heavy goods vehicles with trailers or semi-trailers & $46.82 \%$ & $46.82 \%$ & $46.82 \%$ & $46.82 \%$ & $46.82 \%$ \\
\hline \multirow[t]{5}{*}{ Karoliniškès } & Passenger cars & $47.47 \%$ & $47.47 \%$ & $47.47 \%$ & $47.47 \%$ & $47.47 \%$ \\
\hline & Minibuses & $49.78 \%$ & $49.78 \%$ & $49.78 \%$ & $49.78 \%$ & $49.78 \%$ \\
\hline & Buses & $51.92 \%$ & $51.92 \%$ & $51.92 \%$ & $51.92 \%$ & $51.92 \%$ \\
\hline & Heavy goods vehicles & $51.60 \%$ & $51.60 \%$ & $51.60 \%$ & $51.60 \%$ & $51.60 \%$ \\
\hline & Heavy goods vehicles with trailers or semi-trailers & $49.29 \%$ & $49.29 \%$ & $49.29 \%$ & $49.29 \%$ & $49.29 \%$ \\
\hline \multirow[t]{5}{*}{ Lazdynai } & Passenger cars & $47.12 \%$ & $47.12 \%$ & $47.12 \%$ & $47.12 \%$ & $47.12 \%$ \\
\hline & Minibuses & 48.13 & 48.13 & 48.13 & 48.13 & 48.13 \\
\hline & Buses & 45.98 & 45.98 & 45.98 & 45.98 & 45.98 \\
\hline & Heavy goods vehicles & $49.58 \%$ & $49.58 \%$ & $49.58 \%$ & $49.58 \%$ & $49.58 \%$ \\
\hline & Heavy goods vehicles with trailers or semi-trailers & $48.91 \%$ & $48.91 \%$ & $48.91 \%$ & $48.91 \%$ & $48.91 \%$ \\
\hline
\end{tabular}

In order to accurately determine the driving speed, tests were performed on the Vilnius Western Bypass. The speed of car traffic in Vilnius was also measured. To obtain accurate results, the measuring processes were repeated several times on weekdays during peak and evening traffic (congestion), in the morning and evening traffic (7:00-10:00 and 16:00-20:00 in the opposite direction), during off-peak traffic (10:00-16:00), and at night (20:00-7:00). The traffic flow periods are divided according to the obtained measurement results.

The obtained generalised car flow rates in Vilnius are presented in Table 2.

Standard speed measurements are used to analyse car traffic pollution and urban traffic speed [76]. Measurements made in medium-speed cities by different authors and the results of measurements vary, as they depend on the size of the city, the number of traffic flows and regulated intersections, and the characteristics of regulation. The EU's urban speed limit, the "urban speed standard", is $22.6 \mathrm{~km} / \mathrm{h}$. [77].

Using the measurement data in Tables 3 and 4, describing the number of cars in the traffic flow by type depending on the measurement time in both directions, as well as the average speeds in both directions (Table 3), at the same time distinguishing the individual sections of the bypass, daily pollution calculations are performed on the bypass and city streets.

Table 4. The rating of the Baltic capitals according to different indices and ranking in 2021.

\begin{tabular}{cccccccc}
\hline City & $\begin{array}{c}\text { Quality of } \\
\text { Life Index }\end{array}$ & $\begin{array}{c}\text { Safety } \\
\text { Index }\end{array}$ & $\begin{array}{c}\text { Road Traffic } \\
\text { Death Rate }\end{array}$ & Transport & $\begin{array}{c}\text { Global } \\
\text { Rank }\end{array}$ & CO $_{2}$ & $\begin{array}{c}\text { Air } \\
\text { Quality }\end{array}$ \\
\hline Tallinn & 168.65 & 77.50 & 7 & 10 & 212 & 26 & 6 \\
Vilnius & 165.21 & 72.41 & 10 & 19 & 311 & 23 & 1 \\
Riga & 142.27 & 62.07 & 10.6 & 14 & 287 & 15 & 7 \\
\hline
\end{tabular}

Pollution can be shown for individual sections of the bypass, as well as for individual modes of transport.

When performing the calculations of the number of pollutants, a direct dependence between the number of pollutants and the driving speed was established. As the speeds of the cars on the bypass have a correspondingly lower coefficient of variation of pollutants 
depending on the speed of the traffic, the emissions of all the pollutants analysed are correspondingly lower by a factor of 1.9 .

\section{Discussion}

The security requirements of the social environment of a modern city are inextricably linked to a viable and competitive economy, a healthy environment, social welfare, and ecology.

Cities are ranked according to different methodologies by compiling and calculating different indices. Some of them are presented in Table 4.

As can be seen from Table 4, different indices and ranks show different positions of cities, depending on the index target, and the indicators and methods used.

Scientific sources have also developed many assessment methods and complex indices and conducted many studies evaluating cities and sustainable development $[5,6,33,35,68,78-83]$.

The authors of the article presented a comprehensive assessment of the social environment security of the Baltic capitals in terms of the growing number of road vehicles. Further research could include air transport and inland waterway transport.

It should be emphasised that the situation of air pollution in cities will change over time, one of the reasons being the measures taken by states to address this problem, which could be the focus of further research.

\section{Conclusions}

Transport is one of the most important factors in ensuring economic development and people's quality of life. Investments in transport infrastructure have been shown to have a significant impact on economic growth. It has been observed that the number of registered vehicles is growing every year. Having compared 2020 with 2015, an increase of $19.01 \%$ was observed in Tallinn, $28.14 \%$ in Riga, and $13.76 \%$ in Vilnius. However, given that the main air polluters are thermal power stations and boiler houses, industrial firms, and transport, and the intense concentration of industry and cars is in cities, it is assumed that air pollution is the most likely to contribute to the increase in deaths and morbidity.

When a person chooses the city they want to live in, it is often important for each individual not only to feel safe in a physical sense but also to receive appropriate education and health services, ensure well-being, feel psychological security, and breathe fresh air. Personal safety is one of the many factors that need to be assessed comprehensively. The authors of the article, taking into account the growing number of road transport vehicles and the damage to the security of the social environment, conducted a comprehensive assessment of the social environment in the Baltic capitals.

Having performed the calculations of the number of pollutants, a direct dependence between the number of pollutants and the driving speed was established. As the speeds of the cars on the bypass have a correspondingly lower coefficient of variation of pollutants depending on the speed of the traffic, the emissions of all the pollutants analysed are correspondingly lower by a factor of 1.9 .

An empirical study of the capitals of the Baltic States showed that in 2014-2020, Vilnius took the best position in terms of the increasing number of road vehicles in the social environment security assessment. A very significant gap between Tallinn and Riga was observed in 2020, the reasons for which may be investments in the transport sector, improvement of roads, construction of bypasses, and technical parameters of purchased cars.

The assessment of the social and environmental security of the Baltic capitals in the aspect of increasing road transport based on the MDK model, which is based on the principle of program targeted management, made it possible to predict the influence, importance, and change of factors in the period under review (2014-2020). 
Author Contributions: Conceptualisation, R.V. and R.Č.; methodology, R.V. and I.M.-K.; software, R.Č.; validation, I.M.-K. and R.V.; formal analysis, R.V. and R.Č.; investigation, I.M.-K. and R.Č.; resources, R.Č.; writing—original draft preparation, R.Č. and R.V.; writing-review and editing, I.M.-K.; visualisation, R.Č.; supervision, I.M.-K. All authors have read and agreed to the published version of the manuscript.

Funding: This research received no external funding.

Institutional Review Board Statement: Not applicable.

Informed Consent Statement: Not applicable.

Data Availability Statement: The data of this study is available from the authors upon request.

Conflicts of Interest: The authors declare no conflict of interest.

\section{References}

1. Snieška, V.; Zykienè, I. The Role of Infrastructure in the Future City: Theoretical Perspective. Procedia Soc. Behav. Sci. 2014, 156, 247-251. [CrossRef]

2. Newman, A.; Cooper, B.; Holland, P.; Miao, Q.; Teicher, J. How do industrial relations climate and union instrumentality enhance employee performance? The mediating effects of perceived job security and trust in management. Hum. Resour. Manag. 2019, 58, 35-44. [CrossRef]

3. Čiegis, R.; Ramanauskienè, J. Integruotas darnaus vystymosi vertinimas: Lietuvos atvejis. Vadyb. Moksl. Ir Stud.-Kaimo Verslu Ir Ju Infrastruktūros Plètrai 2011, 2, 39-49.

4. Sinkienè, J. Miesto konkurencingumo veiksniai. Viešoji Polit. Adm. 2008, 25, 68-83. Available online: http://archive.minfolit.lt/ arch/17501/17732.pdf (accessed on 10 October 2020).

5. Bruneckiene, J.; Činčikaitè, R.; Kilijonienè, A. The Specifics of Measurement the Urban Competitiveness at the National and International Level. Eng. Econ. 2012, 23, 256-270. [CrossRef]

6. Činčikaitè, R.; Meidute-Kavaliauskiene, I. An Integrated Competitiveness Assessment of the Baltic Capitals Based on the Principles of Sustainable Development. Sustainability 2021, 13, 3764. [CrossRef]

7. North Atlantic Marine Mammals Commission. Annual Report 2005; NAMMC: Tromsø, Norway, 2005.

8. European Environment Agency. Environmental Indicator Report 2012-Ecosystem Resilience and Resource Efficiency in a Green Economy in Europe; EEA: Copenhagen, Denmark, 2013.

9. Witcher, P. The World Urban Forum: Ideas on the Future of the World's Cities. UN Chron. 2006, 43, 30.

10. Čiegis, A.Ž.R. Darnus Miestų Vystymasis Ir Europos Sajungos Investicijų Isisavinimas. Manag. Theory $2012,1,42-51$.

11. Rutkauskas, A.V. On the Sustainability of Regional Competitiveness Development Considering Risk. Technol. Econ. Dev. Econ. 2008, 14, 89-99. [CrossRef]

12. Arbušauskaitè, N.; Juščenko, A.L. The Social-Demographic Analysis of Cemetery Data: Particularity and Results. Reg. Form. Dev. Stud. 2013, 2, 6-17. [CrossRef]

13. Juškevičius, P. Lietuvos miestu sistemos raida ir jos ateities perspektyvos [The evolution and future prospects of the Lithuanian urban system]. Acta Acad. Artium Vilensis 2015, 76, 11-34.

14. Newman, P.W.G. Sustainability and cities: Extending the metabolism model. Landsc. Urban Plan. 1999, 44, 219-226. [CrossRef]

15. Zhao, C.-R.; Zhou, B.; Su, X. Evaluation of Urban Eco-Security-A Case Study of Mianyang City, China. Sustainability 2014, 6, 2281-2299. [CrossRef]

16. Wu, J. Urban ecology and sustainability: The state-of-the-science and future directions. Landsc. Urban Plan. 2014, 125, 209-221. [CrossRef]

17. Huang, L.; Wu, J.; Yan, L. Defining and measuring urban sustainability: A review of indicators. Landsc. Ecol. 2015, 30, 1175-1193. [CrossRef]

18. Bakıc1, T.; Almirall, E.; Wareham, J. A Smart City Initiative: The Case of Barcelona. J. Knowl. Econ. 2013, 4, 135-148. [CrossRef]

19. Anttiroiko, A.-V.; Valkama, P.; Bailey, S.J. Smart cities in the new service economy: Building platforms for smart services. AI Soc. 2014, 29, 323-334. [CrossRef]

20. Auci, S.; Mundula, L. Smart Cities and a Stochastic Frontier Analysis: A Comparison among European Cities. 2012. Available online: http:/ / ssrn.com/abstract=2150839Electroniccopyavailableat:https: / ssrn.com/abstract=2150839Electroniccopyavailableat: http: / / ssrn.com/abstract=2150839https: / / ssrn.com/abstract=2150839Electroniccopyavailableat:http: / / ssrn.com / abstract=21 50839 (accessed on 20 September 2020).

21. Bojic, I.; Lipic, T.; Podobnik, V. Bio-inspired Clustering and Data Diffusion in Machine Social Networks. In Computational Social Networks; Springer London: London, UK, 2012; pp. 51-79.

22. Fernandez-Anez, V.; Fernández-Güell, J.M.; Giffinger, R. Smart City implementation and discourses: An integrated conceptual model. The case of Vienna. Cities 2018, 78, 4-16. [CrossRef]

23. Caragliu, A.; DEL Bo, C.F.M.; Nijkamp, P. Smart Cities in Europe. J. Urban Technol. 2011, 18, 65-82. [CrossRef] 
24. Lombardi, P.; Giordano, S.; Farouh, H.; Yousef, W. Modelling the smart city performance. Innov. Eur. J. Soc. Sci. Res. 2012, 25, 137-149. [CrossRef]

25. European Commission. European Innovation Partnership on Smart Cities and Communities Operational Implementation Plan: First Public Draft. Smart City Communities 2013, 1, 1-22.

26. Valstybès Pažangos Strategija „Lietuvos Pažangos Strategija „Lietuva 2030“. Lithuania. 2012. Available online: https://e-seimas. lrs.lt/portal/legalAct/lt/TAD/TAIS.425517 (accessed on 3 September 2020).

27. Vyriausybè, L.R. Dèl 2014-2020 Metu Nacionalinès Pažangos Programos Patvirtinimo. Valstyb. Žinios 2012, 12, 1482.

28. Li, X.; Fong, P.S.; Dai, S.; Li, Y. Towards sustainable smart cities: An empirical comparative assessment and development pattern optimization in China. J. Clean. Prod. 2019, 215, 730-743. [CrossRef]

29. Pivorienè, J. Global Education and Social Dimension of Sustainable Development. Soc. Ugdym. 2014, 39, 39-47. [CrossRef]

30. Marin, C.; Dorobanţu, R.; Codreanu, D.; Mihaela, R. The Fruit of Collaboration Between Local Government and Private Partners in the Sustainable Development Community Case Study: County Valcea. Acad. Econ. Stud. Rom. 2012, 15, 93-98. Available online: www.ugb.ro/etc (accessed on 11 October 2020).

31. Cioca, L.-I.; Ivascu, L.; Rada, E.C.; Torretta, V.; Ionescu, G. Sustainable Development and Technological Impact on $\mathrm{CO}_{2}$ Reducing Conditions in Romania. Sustainability 2015, 7, 1637-1650. [CrossRef]

32. Derwent, R.; Hjellbrekke, A.-G. Air Pollution by Ozone across Europe: Handbook of Environmental Chemistry; Springer: Berlin/Heidelberg, Germany, 2019.

33. Bruneckiene, J.; Guzavicius, A.; Cincikaite, R. Measurement of Urban Competitiveness in Lithuania. Eng. Econ. 2010, 21, 493-508.

34. Panda, S.; Chakraborty, M.; Misra, S.K. Assessment of social sustainable development in urban India by a composite index. Int. J. Sustain. Built Environ. 2016, 5, 435-450. [CrossRef]

35. Činčikaitè, R.; Paliulis, N. Assessing Competitiveness of Lithuanian Cities. Econ. Manag. 2013, 18, 490-500. [CrossRef]

36. Barbier, E.B.; Burgess, J.C. The Sustainable Development Goals and the systems approach to sustainability. Econ. Open-Access Open-Assess. E-J. 2017, 11. [CrossRef]

37. Melnikas, B.; Tumalavičius, V.; Šakočius, A.; Bileišis, M.; Ungurytė-Ragauskienè, S.; Giedraitytè, V.; Prakapienė, D.; Guščinskienè, J.; Čiburienè, J.; Dubauskas, G.; et al. Saugumo Iššūkiai: Saugumo Iššūkiai; LKA: Vilnius, Lithuania, 2020; p. 494.

38. Činčikaite, R.; Meidute-Kavaliauskiene, I. Assessment of Social Environment Competitiveness in Terms of Security in the Baltic Capitals. Sustainability 2021, 13, 6932. [CrossRef]

39. Robert, K.W.; Parris, T.M.; Leiserowitz, A.A. What is Sustainable Development? Goals, Indicators, Values, and Practice. Environ. Sci. Policy Sustain. Dev. 2005, 47, 8-21. [CrossRef]

40. Richardson, B.C. Toward a Policy on a Sustainable Transportation System. Transp. Res. Rec. J. Transp. Res. Board 1999, 1670, 27-34. [CrossRef]

41. OECD Annual Report 2000; OECD: Paris, France, 2000.

42. Litman, T. Exploring the Paradigm Shifts Needed to Reconcile Transportation and Sustainability Objectives. Transp. Res. Rec. J. Transp. Res. Board 1999, 1670, 8-12. [CrossRef]

43. European Environment Agency. Sustainable Consumption and Production in Southeast Europe and Eastern Europe, Caucasus and Central Asia; European Environment Agency: Copenhagen, Denmark, 2007.

44. Cederoth, M.; DuMond, M.; Sinistore, J. New Standards for Infrastructure Delivery: California High-Speed Rail. In Proceedings of the International Conference on Sustainable Infrastructure, New York, NY, USA, 26-28 October 2017; pp. $247-258$.

45. Schmitt, J.; Garcia, J.; Ribeiro, J.M.P.; de Guerra, J.B.S.O. The Performance of Brazilian Government Toward Sustainability in the Context of RIO+20 (United Nations Conference on Sustainable Development): An Analysis of the Brazilian Programs and the Importance of Education for Sustainability. In Challenges in Higher Education for Sustainability; Springer: Berlin/Heidelberg, Germany, 2016; pp. 119-146.

46. Barysienè, E.; Speičytè, J. Darnaus transporto sistemos plètojimo Lietuvoje analizè. Moksl. Liet. Ateitis 2009, 1, 77-80. [CrossRef]

47. Litman, T.; Burwell, D. Issues in sustainable transportation. Int. J. Glob. Environ. Issues 2006, 6, 331. [CrossRef]

48. Golinska, M.; Hajduk, P. Sustainable Transport: New Trends and Business Practices; Springer Science \& Business Media: Berlin/Heidelberg, Germany, 2012; p. 346.

49. Rutkovienè, N.S.V.M. Aplinkos Tarša Mokomoji Knyga. 2008. Available online: http://www.lzuu.lt/nm/l-projektas/-Aplinkos_ tarsa/titlas.htm (accessed on 9 October 2020).

50. Égert, B.T.K.D.S. Infrastructure and Growth. Econ. Stud. Inequal. Soc. Exclusion Well-Being 2013, 5-45. [CrossRef]

51. Wang, A. Research of Logistics and Regional Economic Growth. iBusiness 2010, 2, 395-400. [CrossRef]

52. Lietuvos Respublikos Susisiekimo Ministro isakymas. Lietuvos susisiekimo plètros iki 2050 M. Strategija; Lietuvos Respublikos Susisiekimo Ministro įsakymas: Vilnius, Lithuania, 2020; Volume 98.

53. Vaitkus, A.; Čygas, D.; Jasiūnienè, V.; Jateikienè, L.; Andriejauskas, T.; Skrodenis, D.; Ratkevičiūtè, K. Traffic Calming Measures: An Evaluation of the Effect on Driving Speed. Promet Traffic Transp. 2017, 29, 275-285. [CrossRef]

54. Schlich, R.; Schönfelder, S.; Hanson, S.; Axhausen, K.W. Structures of Leisure Travel: Temporal and Spatial Variability. Transp. Rev. 2004, 24, 219-237. [CrossRef]

55. Griškevičiūtè-Gečienè, A.; Burinskienè, M. Towards Creating the Assessment Methodology for Urban Road Transport Development Projects. Technol. Econ. Dev. Econ. 2012, 18, 651-671. [CrossRef] 
56. European Commission. Transport in the European Union: Current Trends and Issues. Eur. Comm. 2018, 1-144. Available online: https:/ / ec.europa.eu/transport/sites/transport/ files/2018-transport-in-the-eu-current-trends-and-issues.pdf (accessed on 10 September 2020).

57. Vitkūnas, R.; Meidutè, I. Evaluation of bypass influence on reducing air polution in Vilnius city. Transport 2011, 26, 43-49. [CrossRef]

58. Steel, N.; Ford, J.; Newton, J.N.; Davis, A.C.J.; Vos, T.; Naghavi, M.; Glenn, S.; Hughes, A.; Dalton, A.M.; Stockton, D.; et al. Changes in health in the countries of the UK and 150 English Local Authority areas 1990-2016: A systematic analysis for the Global Burden of Disease Study 2016. Lancet 2018, 392, 1647-1661. [CrossRef]

59. Cohen, A.J.; Anderson, H.R.; Ostro, B.; Pandey, K.D.; Krzyzanowski, M.; Künzli, N.; Gutschmidt, K.; Pope, A.; Romieu, I.; Samet, J.M.; et al. The Global Burden of Disease Due to Outdoor Air Pollution. J. Toxicol. Environ. Health Part A 2005, 68, 1301-1307. [CrossRef] [PubMed]

60. World Health Statistics 2014. Available online: http:/ / www.springer.com/series/15440\%0Apapers://ae99785b-2213-416d-aa7e3a12880cc9b9/Paper/p18311 (accessed on 10 October 2020).

61. Sierra-Vargas, M.P.; Teran, L.M. Air pollution: Impact and prevention. Respirology 2012, 17, 1031-1038. [CrossRef]

62. Anderson, J.O.; Thundiyil, J.G.; Stolbach, A. Clearing the Air: A Review of the Effects of Particulate Matter Air Pollution on Human Health. J. Med Toxicol. 2011, 8, 166-175. [CrossRef]

63. Bronius, K.; Dèdelè, A. Aplinkos Inžinerija: Mokomoji Knyga; Vytauto Didžiojo Universitetas: Kaunas, Lithuania, $2014 ;$ p. 150.

64. Shi, R.-X.; Geng, L.-S.; Grinstein, B.; Jäger, S.; Camalich, J.M. Revisiting the new-physics interpretation of the b $\rightarrow$ c $\tau v$ data. J. High Energy Phys. 2019, 2019, 65. [CrossRef]

65. Signoretta, P.E.; Buffel, V.; Bracke, P. Mental wellbeing, air pollution and the ecological state. Health Place 2019, 57, 82-91. [CrossRef] [PubMed]

66. Šrám, R.J.; Veleminsky, M.; Stejskalová, J. The impact of air pollution to central nervous system in children and adults. Neuro Endocrinol. Lett. 2017, 38, 389-396.

67. Ginevičius, R.; Podvezko, V.; Mikelis, D. Quantitative Evaluation of Economic and Social Development of Lithuanian Regions. Ekonomika 2004, 65. [CrossRef]

68. Lazauskas, M.; Zavadskas, E.K.; Šaparauskas, J. Ranking of priorities among the baltic capital cities for the development of sustainable construction. E+M Èkon. Manag. 2015, 18, 15-24. [CrossRef]

69. Zavadskas, E.K.; Turskis, Z. Multiple Criteria Decision Making (Mcdm) Methods in Economics: An Overview/Daugiatiksliai Sprendimu Prièmimo Metodai Ekonomikoje: Apžvalga. Technol. Econ. Dev. Econ. 2011, 17, 397-427. [CrossRef]

70. Keliu Transporto Emisijos Faktoriu Skaičiuokle; Fizikos Institutas: Vilnius, Lithuania, 2013; p. 21.

71. Išmetamu I Atmosfera Teršalu Tyrimai, Itvertinimai, Prognoze Bei Antropogeninès Taršos Lygiu Ir Kritiniu Apkrovu Ekosistemoms Vertinimas; Fiziniu Ir Technologijos Mokslu Centras: Vilnius, Lithuania, 2013; p. 63.

72. Paulauskas, V. Benzininiu varikliu taršos eksperimentiniai tyrimai, atkartojant Europos važiavimo ciklą NEDC. Aleksandro Stulginskio Univ. Moksl. Darb. 2012, 44, 33-47.

73. Pikūnas, A. Nuostoliu, Patiriamu Dèl Neigiamos Transporto Poveikio Urbanistinèse Zonose, Ivertinimas; KTU: Vilnius, Lithuania, 2008; p. 51.

74. Regioninè Galimybiu Studija. Transporto Eismo Taršos Tyrimai; Vakaru krantas: Klaipèda, Lithuania, 2018 ; p. 51.

75. Лагерев, Р.Ю. Экологические ОсновыАвтомобильного Транспорта: Методические УказанияПо ВыполнениюПрактических ИСамостоятельных Работ; ИрГТУ: Irkutsk, Russia, 2011; p. 32.

76. Barlow, T.J.; Latham, S.; McCrae, I.S.; Boulter, P.G. A Reference Book of Driving Circles for Use in the Measurment of Road Vehicle Emission; TRL: Berkshire, UK, 2009.

77. Aplinka, Energija Ir Transportas. ES Finansuoto Miesto Transporto Tiriamojo Projekto Rezultatai; Aplinka, Energija Ir Transportas: Copenhagen, Denmark, 2003; p. 28.

78. Pabedinskaite, A.; Činčikaitè, A.K.R. Evaluation of Smart Cities. Manag. Eng. 2016, 1, $273-283$.

79. Akande, A.; Cabral, P.; Gomes, P.; Casteleyn, S. The Lisbon ranking for smart sustainable cities in Europe. Sustain. Cities Soc. 2018, 44, 475-487. [CrossRef]

80. Stanković, J.; Dzunic, M.; Dzunic, Z.; Marinković, S. A Multi-Criteria Evaluation of the European Cities' Smart Performance: Economic, Social and Environmental Aspects. Zb. Rad. Ekon. Fak. Rijeci Časopis Ekon. Teor. Praksu/Proc. Rijeka Fac. Econ. J. Econ. Bus. 2017, 35, 519-550. [CrossRef]

81. Bolívar, M.P.R. In the search for the 'Smart' Source of the Perception of Quality of Life in European Smart Cities. In Proceedings of the 52nd Hawaii International Conference on System Sciences, Maui, HI, USA, 8-11 January 2019. [CrossRef]

82. Gil, M.T.N.; Carvalho, L.; Paiva, I. Determining factors in becoming a sustainable smart city: An empirical study in Europe. Econ. Sociol. 2020, 13, 24-39. [CrossRef]

83. Meidutè-Kavaliauskienè, I.; Dudzevičiūtè, G.; Maknickienè, N. Military and Demographic Inter-Linkages in the Context of the Lithuanian Sustainability. J. Bus. Econ. Manag. 2020, 21, 1508-1524. [CrossRef] 